\title{
EFFECT OF ACETIC ACID AND DATE RESIDUES ON SOME PHYSIOLOGICAL CHARACTERISTICS, PRODUCTIVE AND REPRODUCTIVE PARAMETERS OF QUAIL DURING SUMMER SEASON
}

\author{
W. Fouad ${ }^{1}$, M.E Farag ${ }^{2}$, B.M. Abou-Shehema ${ }^{2}$ and H.A.H. Abd El-Halim ${ }^{3}$ \\ ${ }^{1}$ Poultry Production Department, Faculty of Agriculture, New Valley University, Egypt. \\ 2 \\ Anim. Prod. Res. Institute, Agric. Res. Center, Ministry of Agric., Egypt. \\ ${ }^{3}$ Dep.of Poult. Breed. Res. Anim. Prod. Res. Inst., Agric. Res. Center, Dokki, Giza, Egypt. \\ Corresponding author: Walid Fouad, E-mail: walidfouad99@yahoo.com
}

(Received 11/9/2018, accepted 5/11/2018)

\section{SUMMARY}

$\mathrm{O}$ ne hundred and eight 8 wk-old Japanese quail were distributed randomly into six different dietary treatments in a $2 \times 3$ factorial with three replicates, each containing 6 birds ( 2 males and 4 females), assigning experimental unit to investigate the effect of vinegar (acetic acid) and date residues (date's by-product) on egg production, fertility and hatchability percentages, some physiological characteristics, blood parameters, hormones, antioxidant indices and immunity parameter. Average temperature ranged between $40^{\circ} \mathrm{C}$ and $43^{\circ} \mathrm{C}$ with $50 \%$ relative humidity from 8 to 14 weeks of age. Dietary treatments were date residues levels $(0$ and $10 \%)$ supplemented into diets with three levels of acetic acid $(0.0$, 0.5 and $1 \mathrm{ml} /$ liter water) in drinking water. Results showed that dates residues and vinegar (acetic acid) and interactions between them had significant effect on all the productive performance (egg weight, egg production, egg mass/hen/day, feed conversion as ( $\mathrm{g}$ feed/g egg)) and improved significantly $(\mathrm{P}<0.05)$ fertility and hatchability percentages while decreased significantly $(\mathrm{P}<0.05)$ non pipping embryos $(\%)$ and embryonic mortality (\%). All treatments and interactions between them increased significantly some blood hematological, blood biochemical parameters, antioxidant indices and immunity parameter and hormones of quail, i.e., total protein, albumin, total lipids, HDL, GPX ,GSH, SOD, IgG, progesterone and T3, T4 hormones, but WBCs count in all treatments were slightly increased in number, while serum cholesterol, glucose concentrations, AST and ALT were decreased significantly $(\mathrm{P}<0.05)$ birds' in compared with control group. The nutrients digestibility were improved by treatment groups and interactions between them. The counts of total aerobic and anaerobic bacteria and total coliform of chick intestinal were decreased due to add different treatments compared with the control. In conclusion, It may be the application of date residues 10\% (in feed) with vinegar (acetic acid) in drinking water $(0.5$ or $1 \mathrm{ml} / \mathrm{liter})$ improved the productive performance such as egg production, fertility, hatchability percentages, some physiological parameters and nutrients digestibility of laying Japanese quail during summer season.

Keywords: Quail, vinegar, dates residues, egg production, hatchability, blood parameters.

\section{INTRODUCTION}

Summer months could be a difficult time for poultry production that a problem in many parts of the world. The main consequences of the hot environment are low feed intake and egg production (Peguri and Coon, 1991). It has also been shown that at high ambient temperatures, the potential of physiological birds is sharply reduced (Obidi et al., 2008 and Ayo et al., 2010).

Date palm (Phoenix dactylifera, L.), a member of the family of Arecaceae, is one of the most important wood plants grown in dry or semi-dry regions of the world (Moghaieb et al., 2011). Dates, the fruit of the date palm tree (phoenix dactylifera), are a major food in the arid regions of North Africa and the Middle East, and the date crop plays a major role in the economy and social life of these regions (FAO, 2007)

At the last few years, there have been increasing attempts to use date waste as a production of meat and 


\section{Fouad et al.}

eggs. It is reported that the nitrogen-free extract from date waste with or without the pit allows it to be used as an energy source in poultry diets to reduce feed costs and reduce pollution problems (Soliman, 1996; Hussein et al., 1998; Al-Harthi, 2006; Najib and Al-Yousef, 2012 and Ghasemi et al., 2014). In addition, the secondary product contained about $26.6 \%$ galactose, $71.8 \%$ mannose and 9.8-22.3\% beta-galactomannan polysaccharides which could replace the energy of maize in poultry diets (Ishrud et al., 2001 and Hamada et al., 2002).

Organic acids are routinely incorporated into the monogastric animals diet in Europe as acidifiers and preservatives, to replace antibiotics as promoters of growth and to prevent or control pathogens (Papatsiros et al., 2012 and Sugiharto, 2014).Organic acid (eg, acetic acid) and their slices inhibit the growth of microorganisms in the gastrointestinal tract, altering intestinal $\mathrm{pH}$ and improving feed utilization (Patten and Waldroup, 1998; Owings et al., 1990; Skinner et al., 1991and Adams, 1999). Kadim et al. (2008) note that supplemental ascorbic acid significantly reduces the effects of heat-related stress on the performance of broiler chickens. This suggests that the addition of acetic acid to drinking water may reduce the heat stress conditions in laying hens and improve egg production and quality.

The objective of this study was to evaluate use date residues and acetic acid supplementation on physiological characteristics, egg production, fertility and hatchability percentages of laying Japanese quails reared during summer season.

\section{MATERIALS AND METHODS}

The present study was carried out at Poultry Farm, Faculty of Agriculture, New Valley University. The experiment was conducted during the period between May and June 2017

\section{Experimental diets and design:}

The date of this study was purchased from a local factory in the New Valley Governorate, Egypt. Dates were dried in an automatic oven at $\left(60^{\circ} \mathrm{C}\right)$ for 24 hours, after that dates were ready for grinding with crushing (Abdel Ghani et al., 2004). Natural white vinegar 5\% was purchased from a local company, Egypt. One hundred and eight 8 wk-old Japanese quail (Coturnix coturnix japonica) were weighed to equal live weight in all groups at the beginning of the study. They evenly distributed randomly into six different dietary treatments in a $2 \times 3$ factorial arrangement including two date residues (date's by-product) levels ( 0 and $10 \%)$ supplemented into diets with three levels of acetic acid $(0,0.5$ and $1 \mathrm{ml} /$ liter) in drinking water with three replicates, each containing 6 birds ( 2 males and 4 females).

Quail were allowed ad libitum access to feed and water, and they were housed in wire cages on a 17-h lighting schedule. Chemical composition of the diet was analyzed by the methods of A.O.A.C. (1990). All birds were kept under the same environmental conditions. Average temperature ranged between $40^{\circ} \mathrm{C}$ and $43^{\circ} \mathrm{C}$ with $50 \%$ relative humidity from 8 to 14 weeks of age.

\section{Samples taken and Measurements:}

Productive performance: Egg weight and egg number were recorded daily $8^{\text {th }}$ to $14^{\text {th }}$ weeks of age for each replicate and calculate egg mass (g). Feed conversion ratio (FCR) as $\mathrm{g}$ feed /g egg was calculated and feed intake were recorded. The egg production traits were recorded throughout the experimental period for each treated. Hatchability percentages measuring by recorded the number of the hatched chicks for three days after 17 days of brooding. Then the remaining non-hatched eggs were cracked, and the unfertile eggs, fertile, non piping embryos and embryonic deaths were recorded.

At the end of the experiment (14 weeks of age), three birds from each treated group were randomly chosen, then individually weighed and slaughtered, (the assigned birds were fasted overnight). Three blood samples from each treated group were collected. Aportion of the fresh blood was used to determine blood hematological parameters (Hemoglobin (Hb), Red Blood Cells (RBCs), Packed cells volume (PCV) and the white blood cells (WBCs) and WBCs' fractions were measured. Serum was obtained from the blood samples by centrifugation for $15 \mathrm{~min}$. At $3000 \mathrm{rpm}$ and was stored at $-20 \mathrm{C}^{\mathrm{o}}$ until the time of analysis. Serum samples were analyzed to determine biochemical blood indicators such as (total lipids ,total protein, albumin, cholesterol, high density lipoprotein (HDL), glucose concentration , alkaline phosphatase (ALP) and asparatate amino transferase (AST), antioxidant indices (glutathione peroxidase (GPX), glutathione 
(GSH), superoxide dismutase (SOD), immune indices ( $\mathrm{IgG})$ and hormone $\left(\mathrm{P} 4, \mathrm{~T}_{3}, \mathrm{~T}_{4}\right)$ by using the commercial kits.

Table (1): Composition and calculated analysis of the experimental diet.

\begin{tabular}{lcc}
\hline Ingredient & Basal diet, $\mathrm{g} / \mathrm{kg}$ & date residues, $\mathrm{g} / \mathrm{kg}$ \\
\hline Yellow corn & 600.5 & 493 \\
Soybean meal (44\%) & 250 & 236 \\
Corn gluten meal (62\%) & 57 & 70.5 \\
Calcium diphosphate & 23 & 23 \\
Limestone & 48 & 48 \\
Vit. + Min. premix $(1)$ & 2.5 & 2.5 \\
NaCl & 2 & 2 \\
DL- Methionine & 0.5 & 0.5 \\
L-Lysine HCl & 1.5 & 1.5 \\
Cotton seed oil & 15 & 23 \\
Date residues & & 100 \\
Total & 1000 & 1000 \\
Calculated analysis & & \\
Crude protein $\%$ & 20 & 20 \\
ME (kcal/kg) & 2925 & 2926 \\
Crude fiber \% & 3.32 & 4.64 \\
Crude fat $\%$ & 4.21 & 5.15 \\
Calcium $\%$ & 2.44 & 2,44 \\
Available phosphorus $\%$ & 0.54 & 0.53 \\
Lysine $\%$ & 1.05 & 1.04 \\
Methionine & 0.4 & 0.41 \\
Methionine + Cystine $\%$ & 0.75 & 0.74 \\
\hline (l) & & \\
\hline
\end{tabular}

(1) Layer Vit. + Min. premix: Each $2.5 \mathrm{~kg}$ of vitamins and minerals premix (commercial source pfiezer Co.): consist of Vit. A $12 \mathrm{MIU}$, Vit E15 KIU, Vit. D3 4 MIU, Vit. B1 1g, Vit B2 8g, Vit B6 $2 \mathrm{~g}$, Vit B12 10mg, Pantothonic acid 10.87g, Niacin 30g, Folic acid 1g, Biotin $150 \mathrm{mg}$, Copper $5 \mathrm{~g}$, Iron 15g, manganese 70g, Iodine 0.5g, Selenium 0.15g, Zinc 60g and antioxidant $10 \mathrm{~g}$.

Table (2): Chemical composition of date residues.

\begin{tabular}{lc}
\hline Composition & $\%$ \\
\hline Dry matter\% & 97.45 \\
ME (kcal/kg) & 2699.5 \\
Crude protein\% & 6.40 \\
Crude fat\% & 5.58 \\
Crude fiber\% & 16.4 \\
Nitrogen free extract (sugar + starch \%) & 46.08 \\
\hline
\end{tabular}

The metabolizable energy content of date wastes used was calculated according to Carpenter and Clegg (1956) equation as follows: metabolizable energy $(\mathrm{kcal} / \mathrm{kg})=53+38$ [crude protein $\%+2.25 *$ ether extract $\%+1.1 *$ nitrogen free extract $\%$.

Digestibility of nutrients: at 14 weeks of age, digestibility of nutrients were conducted according to A.O.A.C. (1990) e.g. crude protein (CP), ether extract (EE), crude fiber (CF), dry matter (DM) and nitrogen free extract (NFE) was estimated by subtracting previous components from one hundred and expressed on a dry matter basis. Then the estimation was made according to Han et al. (1976).

Bacteriological count: Total anaerobic count, aerobic plate counts (APC) and total coliform counts were carried out according to American Public Health Association (A.P.H.A, 1985). 
Statistical analysis: Data collected were subjected to Analysis of Variance (ANOVA). Differences among treatments were evaluated according to procedure out lined by Gomez \& Gomez (1983). Significant of differences between means was defined at 5 percent level compared using the Duncan's multiple range test (Duncan, 1955).

\section{RESULTS AND DISCUSSION}

\section{Productive performance:}

Data given in Table (3) shows that date residues irrespective of acetic acid and acetic acid irrespective date residues of level had significantly $(\mathrm{P}<0.05)$ higher effect on all the productive performance (egg weight, egg production and egg mass/hen/day) and improved $(\mathrm{P}<0.05)$ feed conversion as in compared with control (zero date residues or acetic acid). Increasing date residues in the birds fed date residues from zero to $10 \%$, as well as acetic acid supplemented in drinking water from zero, 0.5 or $1 \mathrm{ml}$ acetic acid /liter led to an increase in egg weight by $5.2 \%$ of the control value (zero date residues), 3.9 and $4.3 \%$ of the control value (zero acetic acid), egg production by $10.73 \%$ of the control value (zero date residues), 15.96 and $20.25 \%$ of the control value (zero acetic acid), egg mass/hen/day by $16.41 \%$ of the control value (zero date residues), 20.85 and $25.40 \%$ of the control value (zero acetic acid), while feed conversion decreased by $4.82 \%$ of the control value (zero date residues), 5.2 and $6.3 \%$ of the control value (zero acetic acid), respectively.

Table (3): Effects of date residues and acetic acid on egg production of quail during summer season.

\begin{tabular}{|c|c|c|c|c|}
\hline Trait & $\begin{array}{c}\text { Egg } \\
\text { weight }(g)\end{array}$ & $\begin{array}{c}\text { Egg } \\
\text { production } \%\end{array}$ & $\begin{array}{c}\text { Egg } \\
\text { mass(g/hen/day) }\end{array}$ & $\begin{array}{l}\text { Feed conversion } \\
\text { ratio }(\mathrm{g} \text { feed } / \mathrm{g} \\
\mathrm{egg})\end{array}$ \\
\hline \multicolumn{5}{|c|}{ Date residues (D) effect: } \\
\hline $\mathrm{D}_{0}$ (zero date residues) control & $11.15^{\mathrm{b}}$ & $71.43^{b}$ & $7.98^{\mathrm{b}}$ & $4.35^{\mathrm{a}}$ \\
\hline $\mathrm{D}_{1}(10 \%$ date residues $)$ & $11.73^{\mathrm{a}}$ & $79.10^{\mathrm{a}}$ & $9.29^{\mathrm{a}}$ & $4.14^{b}$ \\
\hline Pooled SEM & 0.08 & 2.09 & 0.29 & 0.04 \\
\hline \multicolumn{5}{|c|}{ Acetic acid (A) effect: } \\
\hline $\mathrm{A}_{0}$ (zero acetic acid) control & $11.12^{\mathrm{b}}$ & $67.16^{\mathrm{c}}$ & $7.48^{c}$ & $4.42^{\mathrm{a}}$ \\
\hline $\mathrm{A}_{1}(0.5 \mathrm{ml} /$ liter $)$ acetic acid & $11.59^{\mathrm{a}}$ & $77.88^{\mathrm{b}}$ & $9.04^{\mathrm{b}}$ & $4.19^{b}$ \\
\hline $\mathrm{A}_{2}(1 \mathrm{ml} /$ liter $)$ acetic acid & $11.60^{\mathrm{a}}$ & $80.76^{\mathrm{a}}$ & $9.38^{\mathrm{a}}$ & $4.14^{b}$ \\
\hline Pooled SEM & 0.13 & 1.74 & 0.29 & 0.05 \\
\hline \multicolumn{5}{|c|}{ Interactions between date residues (D) and acetic acid (A) : } \\
\hline $\mathrm{D}_{0} \mathrm{X} \mathrm{\textrm {A } _ { 0 }}$ & $10.81^{\mathrm{e}}$ & $63.09^{\mathrm{f}}$ & $6.82^{\mathrm{f}}$ & $4.43^{\mathrm{a}}$ \\
\hline $\mathrm{D}_{0} \mathrm{X} \mathrm{A}_{1}$ & $11.36^{\mathrm{d}}$ & $73.61^{\mathrm{d}}$ & $8.36^{\mathrm{d}}$ & $4.33^{b}$ \\
\hline $\mathrm{D}_{0} \mathrm{X} \mathrm{A_{2 }}$ & $11.28^{\mathrm{c}}$ & $77.58^{\mathrm{c}}$ & $8.75^{\mathrm{c}}$ & $4.30^{\mathrm{b}}$ \\
\hline $\mathrm{D}_{1} \mathrm{X \textrm {A } _ { 0 }}$ & $11.43^{\mathrm{c}}$ & $71.23^{\mathrm{e}}$ & $8.14^{\mathrm{e}}$ & $4.40^{\mathrm{ab}}$ \\
\hline $\mathrm{D}_{1} \mathrm{X} \mathrm{A}_{1}$ & $11.83^{\mathrm{b}}$ & $82.14^{\mathrm{b}}$ & $9.72^{b}$ & $4.04^{\mathrm{c}}$ \\
\hline $\mathrm{D}_{1} \times \mathrm{A}_{2}$ & $11.92^{\mathrm{a}}$ & $83.92^{\mathrm{a}}$ & $10.00^{\mathrm{a}}$ & $3.98^{\mathrm{c}}$ \\
\hline Pooled SEM & 0.0 & 0.48 & 0.05 & 0.03 \\
\hline
\end{tabular}

Means with the same letters are not significantly differed at $(P<0.05)$ according to Duncan's multiple range test.

There were significant interactions between adding dietary date residues into diets and acetic acid levels into water used in the present study on all the productive performance as shown in Table (3). Result showed that bird treated by $1 \mathrm{ml}$ acetic acid/liter water and date residues $(10 \%)$ into diets had the higher $(\mathrm{P}<0.05)$ egg weight, egg production, egg mass and improved $(\mathrm{P}<0.05)$ feed conversion as compared with the other dietary treatments. In agreement with the present study, Jensen and Chang (1976), Gama et al. (2000), Yesibag and Colpan (2006) and Soltan (2008) reported that organic acid supplementation had positive effects on egg production in laying hens. In this respect, Whitehead et al. (1998) and Kirunda et al. (2001) 
found that egg production decreased due to elevated of environmental temperature. They suggested that the decline in egg production was most likely due to reduced feed consumption in chickens and reduction of available nutrients for egg production. This depression can be attributed to the high ambient temperature and its impact on the different physiological characteristics of the chickens. According to Mahdavi et al. (2005), the effect of organic acid on poultry production depends on the intestinal flora and environmental temperatures. High ambient temperatures lead to reduced vitamin and mineral serum concentrations in poultry (Anderson, 1987), resulting in lower egg production. It has been suggested that the effects of organic acids include an improvement in the digestibility and retention of nutrients, as well as modifying the population microbes in the digestive system (Caja et al., 2000).In addition, organic acid has been proposed to improve digestive enzyme activity microbial phytase activity, increase pancreatic secretion and increase the growth of gastrointestinal mucosa (Dibner and Buttin, 2002) and promotes intestinal absorption of nutrients in ligated duodenal loops (Combs and Pesti, 1976). Kadim et al. (2008) reported that, acetic acid can be used during hot months to reduce heat stress and improve egg weight, egg production, diameter and length of eggs from the laying hens between 30-40 weeks of age. This indicates that acetic acid has a potential effect on some stresses, allowing better egg production and egg weight.

Addition of date residues may also stimulate feed and energy consumption at high temperatures, which in turn, provide better performance response and increase the energy value of the other feed constituents. In addition, the secondary product contained about $26.6 \%$ galactose, $71.8 \%$ mannose and $9.8-22.3 \%$ betagalactomannan polysaccharides which could replace the energy of maize in poultry diets (Ishrud et al., 2001 and Hamada et al., 2002). Hermes and Al-Homidan (2004) reported that layer hens fed diets containing $10 \%$ date pits meal enhanced the egg weight, feed conversion ratio ( $\mathrm{kg}$ feed $/ \mathrm{kg}$ egg), egg production and egg mass. However, Najib and Al-Yousef (2012) found that layer hens fed 10\% date pits meal without enzymes improved the feed consumption, feed conversion ratio, egg production and egg mass, but reduced egg size compared to those fed $15 \%$ date pits meal without enzymes. Torki et al. (2014) found that hens fed on the diet containing $10 \%$ whole date waste $(\mathrm{P}<0.05)$ had the highest value of egg weight.

\section{Fertility and hatchability percentages:}

Data given in Table (4) shows that date residues irrespective of acetic acid and acetic acid irrespective date residues of level had a significant $(\mathrm{P}<0.05)$ increasing in fertility and hatchability percentages while non pipping embryos $(\%)$ and embryonic mortality $(\%)$ were significantly $(\mathrm{P}<0.05)$ decreased compared with the control (zero date residues or acetic acid ). Increasing date residues in the birds fed date residues from zero to $10 \%$, as well as acetic acid supplemented in drinking water from zero, 0.5 or $1 \mathrm{ml}$ acetic acid $/ 1$ water led to an increase in fertility by $8.89 \%$ of the control value (zero date residues), 11.28 and $14.35 \%$ of the control value (zero acetic acid), hatchability percentages by $10.89 \%$ of the control value (zero date residues) , 12.47 and $18.99 \%$ of the control value (zero acetic acid, while non pipping embryos decreased by $20.63 \%$ of the control value (zero date residues), 30.72 and $37.52 \%$ of the control value (zero acetic acid), embryonic mortality \% by $28.14 \%$ of the control value (zero date residues), 16.04 and $35.64 \%$ of the control value (zero acetic acid), respectively.

There were significant interactions between adding dietary date residues into diets and acetic acid levels into water used in the present study on fertility and hatchability percentages as shown in Table (4). Result showed that bird treated by $1 \mathrm{ml} / 1$ acetic acid in water and date residues $(10 \%)$ into diets had the higher $(\mathrm{P}<0.05)$ fertility and hatchability percentages and decreased $(\mathrm{P}<0.05)$ non pipping embryos \% and embryonic mortality \% compared with the other dietary treatments. In this respect, Deeming and Ferguson (1991), reported the effect of temperature on hatching, and Lourens et al. (2005) emphasized the adverse effects of temperature on embryonic development of chicks. It can be argued that the increase in hatchability may be due to the supplementation of organic acids in drinking water that improve the quality of the internal eggs, which is consistent with Gama et al. (2000), Yalcin et al. (2000) and Soltan (2008).

\section{Blood constituents and hormones:}

Data given in Tables $(5,6$ and 7) shows that date residues irrespective of acetic acid and acetic acid irrespective date's by-product of level had a significant $(\mathrm{P}<0.05)$ increasing in hematological traits of quail parameters RBCs, $\mathrm{Hb}, \mathrm{PCV}$, but there were no significant on the WBCs and WBCs' fractions and had a significant $(\mathrm{P}<0.05)$ increasing in blood biochemical parameters of quail ,i.e., (total protein, albumin, total lipids and HDL, antioxidant indices (GPX), GSH, SOD, immune indices ( $\mathrm{IgG})$ and hormone $\left(\mathrm{P}_{4}\right.$, thyroid hormone $\left(\mathrm{T}_{4}\right)$ and triiodothyronine $\left(\mathrm{T}_{3}\right)$ ), while serum cholesterol, glucose concentration, and AST and ALT were significantly $(\mathrm{P}<0.05)$ decreased compared with the control (zero date residues or acetic acid ). 


\section{Fouad et al.}

Table (4): Effects of date residues and acetic acid on fertility (\%), hatchability (\%), non pipping embryos (\%) and embryonic mortality (\%) of quail during summer season.

\begin{tabular}{|c|c|c|c|c|}
\hline Trait & $\begin{array}{c}\text { Fertility } \\
(\%)\end{array}$ & $\begin{array}{c}\text { Hatchability } \\
(\%)\end{array}$ & $\begin{array}{l}\text { Non pipping } \\
\text { embryos }(\%)\end{array}$ & $\begin{array}{c}\text { Embryonic } \\
\text { Mortality (\%) }\end{array}$ \\
\hline \multicolumn{5}{|c|}{ Date residues (D) effect: } \\
\hline $\mathrm{D}_{0}$ (zero date residues) control & $80.42^{b}$ & $69.02^{b}$ & $16.09^{\mathrm{a}}$ & $14.89^{\mathrm{a}}$ \\
\hline $\mathrm{D}_{1}(10 \%$ date residues $)$ & $87.57^{\mathrm{a}}$ & $76.54^{\mathrm{a}}$ & $12.77^{\mathrm{b}}$ & $10.70^{b}$ \\
\hline Pooled SEM & 1.78 & 1.88 & 1.17 & 0.89 \\
\hline \multicolumn{5}{|c|}{ Acetic acid (A) effect: } \\
\hline $\mathrm{A}_{0}$ (zero acetic acid) control & $77.38^{\mathrm{c}}$ & $65.87^{\mathrm{c}}$ & $18.68^{\mathrm{a}}$ & $15.46^{\mathrm{a}}$ \\
\hline $\mathrm{A}_{1}(0.5 \mathrm{ml} /$ liter $)$ acetic acid & $86.11^{\mathrm{b}}$ & $74.09^{b}$ & $12.94^{b}$ & $12.98^{b}$ \\
\hline $\mathrm{A}_{2}(1 \mathrm{ml} /$ liter $)$ acetic acid & $88.49^{\mathrm{a}}$ & $78.38^{\mathrm{a}}$ & $11.67^{\mathrm{b}}$ & $9.95^{c}$ \\
\hline Pooled SEM & 1.317 & 1.75 & 0.95 & 1.00 \\
\hline \multicolumn{5}{|c|}{ Interactions between date residues (D) and acetic acid (A) : } \\
\hline $\mathrm{D}_{0} \mathrm{X} \mathrm{A_{0 }}$ & $72.22^{\mathrm{d}}$ & $61.54^{\mathrm{e}}$ & $21.97^{\mathrm{a}}$ & $16.49^{\mathrm{a}}$ \\
\hline $\mathrm{D}_{0} \mathrm{X} \mathrm{A}_{1}$ & $84.12^{\mathrm{c}}$ & $69.81^{\mathrm{d}}$ & $14.16^{\mathrm{bc}}$ & $16.03^{\mathrm{a}}$ \\
\hline $\mathrm{D}_{0} \mathrm{X} \mathrm{A_{2 }}$ & $84.92^{\mathrm{c}}$ & $75.71^{\mathrm{c}}$ & $12.14^{\mathrm{cd}}$ & $12.14^{\mathrm{b}}$ \\
\hline $\mathrm{D}_{1} \mathrm{X} \mathrm{\textrm {A } _ { 0 }}$ & $82.54^{\mathrm{c}}$ & $70.20^{\mathrm{d}}$ & $15.38^{\mathrm{b}}$ & $14.43^{\mathrm{a}}$ \\
\hline $\mathrm{D}_{1} \mathrm{X} \mathrm{\textrm {A } _ { 1 }}$ & $88.09^{b}$ & $78.37^{\mathrm{b}}$ & $11.72^{\mathrm{cd}}$ & $9.92^{\mathrm{c}}$ \\
\hline $\mathrm{D}_{1} \mathrm{X} \mathrm{A_{2 }}$ & $92.07^{\mathrm{a}}$ & $81.04^{\mathrm{a}}$ & $11.20^{\mathrm{d}}$ & $7.76^{\mathrm{d}}$ \\
\hline Pooled SEM & 0.89 & 0.75 & 0.77 & 0.51 \\
\hline
\end{tabular}

Table (5): Effects of date residues and acetic acid on hematological traits of quail during summer season.

\begin{tabular}{|c|c|c|c|c|c|c|c|c|}
\hline Trait & $\begin{array}{r}\mathrm{RBC} \\
(106 / \mathrm{mm} 3)\end{array}$ & $\begin{array}{l}\mathrm{HB} \\
(\mathrm{g} / \mathrm{dl})\end{array}$ & $\begin{array}{l}\text { PCV } \\
\%\end{array}$ & $\begin{array}{l}\text { WBC } \\
(103 / \mathrm{mm} 3)\end{array}$ & $\begin{array}{l}\text { Lymphoc } \\
\text { ytes (\%) }\end{array}$ & $\begin{array}{l}\text { Neutrophils } \\
(\%)\end{array}$ & $\begin{array}{l}\text { Monocytes } \\
(\%)\end{array}$ & $\begin{array}{l}\text { Eosinophils } \\
(\%)\end{array}$ \\
\hline \multicolumn{9}{|l|}{ Date residues (D) effect: } \\
\hline $\mathrm{D}_{0}$ (zero date residues) control & $2.77^{\mathrm{b}}$ & $13.31^{\mathrm{b}}$ & $32.58^{\mathrm{b}}$ & 45.06 & 50.94 & 43.16 & 3.59 & 2.31 \\
\hline$D_{1}(10 \%$ date residues $)$ & $3.33^{\mathrm{a}}$ & $14.50^{\mathrm{a}}$ & $35.02^{\mathrm{a}}$ & 45.26 & 51.43 & 43.18 & 3.38 & 2.00 \\
\hline Pooled SEM & 0.11 & 0.27 & 0.61 & 0.06 & 0.19 & 0.21 & 0.15 & 0.21 \\
\hline \multicolumn{9}{|l|}{ Acetic acid (A) effect: } \\
\hline $\mathrm{A}_{0}$ (zero acetic acid) control & $2.67^{\mathrm{c}}$ & $13.01^{\mathrm{c}}$ & $31.61^{\mathrm{c}}$ & 45.08 & 50.92 & 43.23 & 3.57 & 2.28 \\
\hline $\mathrm{A}_{1}(0.5 \mathrm{ml} /$ liter $)$ acetic acid & $3.04^{\mathrm{b}}$ & $13.92^{b}$ & $34.06^{\mathrm{b}}$ & 45.20 & 51.32 & 43.32 & 3.55 & 1.82 \\
\hline $\mathrm{A}_{2}(1 \mathrm{ml} /$ liter $)$ acetic acid & $3.43^{\mathrm{a}}$ & $14.79^{\mathrm{a}}$ & $35.72^{\mathrm{a}}$ & 45.22 & 51.33 & 42.95 & 3.35 & 2.37 \\
\hline Pooled SEM & 0.13 & 0.27 & 0.55 & 0.08 & 0.25 & 0.25 & 0.18 & 0.24 \\
\hline \multicolumn{9}{|c|}{ Interactions between date residues (D) and acetic acid (A) : } \\
\hline $\mathrm{D}_{0} \times \mathrm{A}_{0}$ & $2.63^{\mathrm{f}}$ & $12.42^{\mathrm{e}}$ & $31.16^{\mathrm{f}}$ & 44.99 & 50.77 & 43.06 & 3.60 & 2.56 \\
\hline $\mathrm{D}_{0} \mathrm{X} \mathrm{A}_{1}$ & $2.76^{\mathrm{d}}$ & $13.66^{\mathrm{d}}$ & $32.25^{\mathrm{d}}$ & 45.15 & 51.20 & 43.50 & 3.50 & 1.80 \\
\hline $\mathrm{D}_{0} \mathrm{X} \mathrm{A}_{2}$ & $2.91^{\mathrm{c}}$ & $13.84^{\mathrm{c}}$ & $34.32^{\mathrm{c}}$ & 45.05 & 50.86 & 42.90 & 3.67 & 2.56 \\
\hline $\mathrm{D}_{1} \times \mathrm{A}_{0}$ & $2.71^{\mathrm{e}}$ & $13.59^{\mathrm{d}}$ & $32.08^{\mathrm{e}}$ & 45.15 & 51.07 & 43.40 & 3.53 & 2.00 \\
\hline $\mathrm{D}_{1} \times \mathrm{A}_{1}$ & $3.32^{\mathrm{b}}$ & $14.17^{b}$ & $35.86^{\mathrm{b}}$ & 45.25 & 51.43 & 43.13 & 3.60 & 1.83 \\
\hline $\mathrm{D}_{1} \times \mathrm{A}_{2}$ & $3.95^{\mathrm{a}}$ & $15.74^{\mathrm{a}}$ & $37.11^{\mathrm{a}}$ & 45.39 & 51.80 & 43.00 & 3.03 & 2.17 \\
\hline Pooled SEM & 0.01 & 0.02 & 0.03 & 0.09 & 0.30 & 0.30 & 0.23 & 0.35 \\
\hline
\end{tabular}

Means with the same letters are not significantly differed at $(P<0.05)$ according to Duncan's multiple range test.

There were significant interactions between adding dietary date residues into diets and acetic acid levels into water used in the present study on hematological traits, blood biochemical parameters, antioxidant indices, immune indices and hormones as shown in Tables (5,6 and 7). Result showed that bird treated by $1 \mathrm{ml} /$ liter acetic acid in water and date residues $(10 \%)$ into diets had the higher $(\mathrm{P}<0.05)$ blood constituents but were no significant on the white blood cells (WBCs) and WBCs' fractions while serum cholesterol, glucose concentration, and AST and ALT were significantly $(\mathrm{P}<0.05)$ decreased compared with the control (zero date residues or acetic acid ). The current results are consistent with the results of Donkoh (1989), Kutlu and Forbes (1993) and Khan et al. (2002) which had shown that heating increases the blood glucose. 
Table (6): Effects of date residues and acetic acid on biochemical blood constituents of quails during summer season.

\begin{tabular}{|c|c|c|c|c|c|c|c|c|}
\hline Trait & $\begin{array}{l}\text { Total protein } \\
(\mathrm{g} / \mathrm{dl})\end{array}$ & $\begin{array}{l}\text { Albumin } \\
(\mathrm{g} / \mathrm{dl})\end{array}$ & $\begin{array}{l}\text { Total } \\
\text { lipids } \\
(\mathrm{mg} / \mathrm{dl})\end{array}$ & $\begin{array}{l}\text { Cholesterol } \\
(\mathrm{mg} / \mathrm{dl})\end{array}$ & $\begin{array}{l}\mathrm{HDL} \\
(\mathrm{mg} / \mathrm{dl})\end{array}$ & $\begin{array}{l}\text { Glucose } \\
(\mathrm{mg} / \mathrm{dl})\end{array}$ & $\begin{array}{l}\mathrm{AST} \\
\text { (U/L) }\end{array}$ & $\begin{array}{l}\text { ALT } \\
\text { (U/L) }\end{array}$ \\
\hline $\begin{array}{l}\text { Date residues (D) effect: } \\
\mathrm{D}_{0} \text { (zero date residues) } \\
\text { control }\end{array}$ & $2.53^{\mathrm{b}}$ & $1.41^{\mathrm{b}}$ & $325.66^{b}$ & $171.89^{\mathrm{a}}$ & $40.33^{b}$ & $265.56^{\mathrm{a}}$ & $45.98^{\mathrm{a}}$ & $20.06^{\mathrm{a}}$ \\
\hline $\mathrm{D}_{1}$ (10\% date residues) & $2.90^{\mathrm{a}}$ & $1.73^{\mathrm{a}}$ & $364.78^{\mathrm{a}}$ & $160.22^{b}$ & $42.89^{\mathrm{a}}$ & $249.44^{b}$ & $43.67^{b}$ & $19.11^{\mathrm{b}}$ \\
\hline $\begin{array}{l}\text { Pooled SEM } \\
\text { Acetic acid (A) effect: }\end{array}$ & 0.11 & 0.05 & 9.19 & 3.30 & 1.14 & 0.57 & 0.55 & 0.29 \\
\hline $\mathrm{A}_{0}$ (zero acetic acid) control & $2.31^{\mathrm{c}}$ & $1.34^{\mathrm{c}}$ & $310.33^{c}$ & $178.83^{\mathrm{a}}$ & $37.50 \mathrm{c}$ & $271.00 \mathrm{a}$ & $46.50 \mathrm{a}$ & $20.53^{\mathrm{a}}$ \\
\hline $\mathrm{A}_{1}(0.5 \mathrm{ml} /$ liter $)$ acetic acid & $2.75^{b}$ & $1.64^{b}$ & $353.00^{b}$ & $162.00^{\mathrm{b}}$ & $42.33 \mathrm{~b}$ & $253.50 \mathrm{~b}$ & $44.73 \mathrm{~b}$ & $19.38^{\mathrm{b}}$ \\
\hline $\mathrm{A}_{2}(1 \mathrm{ml} /$ liter $)$ acetic acid & $3.09^{\mathrm{a}}$ & $1.73^{\mathrm{a}}$ & $372.33^{\mathrm{a}}$ & $157.33^{c}$ & $45.00 \mathrm{a}$ & $248.00 \mathrm{c}$ & $43.27 \mathrm{c}$ & $18.83^{\mathrm{c}}$ \\
\hline Pooled SEM & 0.08 & 0.07 & 8.78 & 2.71 & 0.72 & 3.85 & 0.62 & 0.28 \\
\hline \multicolumn{9}{|c|}{ Interactions between date residues (D) and acetic acid (A): } \\
\hline $\mathrm{D}_{0} \mathrm{X} \mathrm{A}_{0}$ & $2.23^{\mathrm{f}}$ & $1.23^{\mathrm{f}}$ & $289.67^{\mathrm{e}}$ & $179.67^{\mathrm{a}}$ & $37.00^{\mathrm{d}}$ & $276.67^{\mathrm{a}}$ & $47.20^{\mathrm{a}}$ & $20.73^{\mathrm{a}}$ \\
\hline $\mathrm{D}_{0} \mathrm{X} \mathrm{A}_{1}$ & $2.47^{\mathrm{d}}$ & $1.48^{\mathrm{d}}$ & $332.00^{\mathrm{d}}$ & $169.66^{\mathrm{b}}$ & $41.00^{\mathrm{c}}$ & $264.33^{b}$ & $46.17^{b}$ & $20.00^{a b}$ \\
\hline $\mathrm{D}_{0} \mathrm{X} \mathrm{A}_{2}$ & $2.89^{c}$ & $1.52^{c}$ & $355.33^{c}$ & $166.33^{c}$ & $43.00^{\mathrm{c}}$ & $255.66^{\mathrm{c}}$ & $44.60^{b c}$ & $19.43^{b c}$ \\
\hline $\mathrm{D}_{1} \mathrm{X} \mathrm{A_{0 }}$ & $2.39^{\mathrm{e}}$ & $1.44^{\mathrm{e}}$ & $331.00^{\mathrm{d}}$ & $178.00^{\mathrm{a}}$ & $38.00^{\mathrm{d}}$ & $265.33^{b}$ & $45.80^{a b}$ & $20.33^{\mathrm{a}}$ \\
\hline $\mathrm{D}_{1} \mathrm{X} \mathrm{A}_{1}$ & $3.02^{b}$ & $1.80^{b}$ & $374.00^{b}$ & $154.33^{d}$ & $43.67^{b}$ & $242.67^{\mathrm{d}}$ & $43.30^{\mathrm{cd}}$ & $18.76^{\mathrm{cd}}$ \\
\hline $\mathrm{D}_{1} \mathrm{X} \mathrm{A_{2 }}$ & $3.30^{\mathrm{a}}$ & $1.94^{\mathrm{a}}$ & $389.33^{\mathrm{a}}$ & $148.33^{\mathrm{e}}$ & $47.00^{\mathrm{a}}$ & $240.33^{d}$ & $41.93^{\mathrm{d}}$ & $18.23^{\mathrm{d}}$ \\
\hline Pooled SEM & 0.02 & 0.01 & 1.27 & 0.79 & 0.62 & 1.76 & 0.53 & 0.26 \\
\hline
\end{tabular}

Means with the same letters are not significantly differed at $(P<0.05)$ according to Duncan's multiple range test.

Table (7): Effects of date residues and acetic acid on antioxidant indices, immune indices and hormones of quails during summer season.

\begin{tabular}{|c|c|c|c|c|c|c|c|}
\hline \multirow[t]{2}{*}{ Trait } & \multicolumn{4}{|c|}{ Antioxidant indices and immunity parameter } & \multicolumn{3}{|c|}{ hormones } \\
\hline & GPX (U/L) & GSH (U/L) & SOD (U/L) & $\begin{array}{c}\mathrm{IgG} \\
(\mathrm{mg} / 100 \mathrm{ml})\end{array}$ & $\begin{array}{c}\mathrm{P}_{4} \\
\text { (ng/dl) }\end{array}$ & $\begin{array}{c}\mathrm{T}_{3} \\
\text { (ng/ml) }\end{array}$ & $\begin{array}{c}\mathrm{T}_{4} \\
\text { (ng/ml) }\end{array}$ \\
\hline \multicolumn{8}{|l|}{ Date residues (D) effect: } \\
\hline $\mathrm{D}_{0}$ (zero date residues) control & $38.34^{b}$ & $974.55^{b}$ & $235.11^{\mathrm{b}}$ & $967.22^{b}$ & $1.49^{\mathrm{b}}$ & $2.18^{\mathrm{a}}$ & $11.61^{\mathrm{b}}$ \\
\hline $\mathrm{D}_{1}(10 \%$ date residues $)$ & $40.27^{\mathrm{a}}$ & $981.00^{\mathrm{a}}$ & $240.67^{\mathrm{a}}$ & $973.11^{\mathrm{a}}$ & $1.86^{\mathrm{a}}$ & $1.96^{\mathrm{b}}$ & $12.74^{\mathrm{a}}$ \\
\hline Pooled SEM & 0.51 & 1.58 & 1.34 & 1.85 & 0.08 & 0.07 & 0.35 \\
\hline \multicolumn{8}{|l|}{ Acetic acid (A) effect: } \\
\hline $\mathrm{A}_{0}$ (zero acetic acid) control & $37.43^{c}$ & $972.67^{\mathrm{c}}$ & $233.33^{b}$ & $963.16^{\mathrm{c}}$ & $1.38^{\mathrm{c}}$ & $2.35^{\mathrm{a}}$ & $10.92^{\mathrm{c}}$ \\
\hline $\mathrm{A}_{1}(0.5 \mathrm{ml} /$ liter $)$ acetic acid & $39.85^{b}$ & $978.33^{b}$ & $239.16^{\mathrm{a}}$ & $972.17^{\mathrm{b}}$ & $1.73^{\mathrm{b}}$ & $2.05^{\mathrm{b}}$ & $12.33^{\mathrm{b}}$ \\
\hline $\mathrm{A}_{2}(1 \mathrm{ml} /$ liter $)$ acetic acid & $40.65^{\mathrm{a}}$ & $982.33^{\mathrm{a}}$ & $241.17^{\mathrm{a}}$ & $975.16^{\mathrm{a}}$ & $1.91^{\mathrm{a}}$ & $1.82^{\mathrm{c}}$ & $13.28^{\mathrm{a}}$ \\
\hline Pooled SEM & 0.47 & 1.73 & 1.52 & 1.42 & 0.08 & 0.05 & 0.26 \\
\hline \multicolumn{8}{|c|}{ Interactions between date residues (D) and acetic acid (A): } \\
\hline $\mathrm{D}_{0} \mathrm{X} \mathrm{A_{0 }}$ & $37.13^{\mathrm{d}}$ & $971.67^{\mathrm{d}}$ & $232.33^{\mathrm{c}}$ & $961.00^{\mathrm{e}}$ & $1.35^{\mathrm{e}}$ & $2.41^{\mathrm{a}}$ & $10.56^{\mathrm{e}}$ \\
\hline $\mathrm{D}_{0} \mathrm{X} \mathrm{A_{1 }}$ & $38.40^{\mathrm{c}}$ & $974.33^{\mathrm{cd}}$ & $235.33^{\mathrm{c}}$ & $968.33^{\mathrm{c}}$ & $1.45^{\mathrm{d}}$ & $2.22^{\mathrm{c}}$ & $11.47^{\mathrm{d}}$ \\
\hline $\mathrm{D}_{0} \mathrm{X} \mathrm{A}_{2}$ & $39.50^{\mathrm{b}}$ & $977.67^{\mathrm{c}}$ & $237.66^{b}$ & $972.33^{b}$ & $1.65^{\mathrm{c}}$ & $1.93^{\mathrm{d}}$ & $12.80^{\mathrm{c}}$ \\
\hline $\mathrm{D}_{1} \mathrm{X} \mathrm{A_{0 }}$ & $37.73^{\mathrm{cd}}$ & $973.66^{\mathrm{cd}}$ & $234.33^{c}$ & $965.33^{d}$ & $1.41^{\mathrm{d}}$ & $2.28^{\mathrm{b}}$ & $11.27^{\mathrm{d}}$ \\
\hline $\mathrm{D}_{1} \mathrm{X} \mathrm{A_{1 }}$ & $41.30^{\mathrm{a}}$ & $982.33^{b}$ & $243.00^{\mathrm{a}}$ & $976.00^{\mathrm{a}}$ & $2.00^{\mathrm{b}}$ & $1.88^{\mathrm{d}}$ & $13.20^{b}$ \\
\hline $\mathrm{D}_{1} \mathrm{X} \mathrm{A_{2 }}$ & $41.80^{\mathrm{a}}$ & $987.00^{\mathrm{a}}$ & $244.67^{\mathrm{a}}$ & $978.00^{\mathrm{a}}$ & $2.17^{\mathrm{a}}$ & $1.72 \mathrm{e}$ & $13.77^{\mathrm{a}}$ \\
\hline Pooled SEM & 0.24 & 1.22 & 1.22 & 0.80 & 0.01 & 0.01 & 0.09 \\
\hline
\end{tabular}

Means with the same letters are not significantly differed at $(P<0.05)$ according to Duncan's multiple range test.

level of birds. They concluded that high glucose may be attributed to increased secretion of glucocorticoids which increases glucogenesis. Abramyan and Kostanyan (1990) reported that heat stress significantly reduced the concentration of total protein in the blood of birds. Guo et al. (1998) found that exposure to high temperatures led to a significant reduction in cholesterol. Sahin et al. (2001) showed a significant negative impact of heat stress on total proteins in broiler chickens. Significant adverse effects of 


\section{Fouad et al.}

heat stress $\left(32^{\circ} \mathrm{C}\right.$ on serum concentration of some minerals and metabolites in broilers. Levels of serum $\mathrm{T}_{4}$ and $\mathrm{T}_{3}$ decreased significantly due to high level of adrenocorticotropic hormone in control compared to values obtained in birds that received antioxidant feed supplements. Also, Novero et al. (1991) showed that progesterone levels were significantly lower in hens exposed to heat stress than control.

Organic acid supplementation showed no significant difference $(\mathrm{P}>0.05)$ in the concentration of blood glucose, cholesterol, triglycerides, creatinine, LDL and HDL among all groups (Hernández et al., 2006 $(\mathrm{P}<0.05)$ Adil et al., 2010). Abdel-Fattah et al. (2008) concluded that dietary supplements of organic acids could be reach a level of $3 \%$ in the diet of broiler chicken without causing any adverse effect on liver functions and kidney. On the other hand, Fouad and Saleh (2017) reported that date wastes had a significant effect on some biochemical parameters of blood and quail hormones, i.e., total protein, albumin, total lipids, HDL, progesterone and triiodothyronine hormones were increased, while serum cholesterol and glucose concentrations were decreased significantly $(\mathrm{P}<0.05)$ for birds compared to control group.

\section{Digestibility of nutrients:}

Data given in Table (8) shows that date residues irrespective of acetic acid and acetic acid irrespective date's by-product of level and interactions had a significantly $(\mathrm{P}<0.05)$ ) different effect on crude protein (CP) but were no significant on digestibility of ether extract (EE), crude fiber (CF), and NFE in compared with the control (zero date residues or acetic acid ). Result showed that bird treated by $1 \mathrm{ml} / 1$ acetic acid in water and date wastes (10\%) into diets had the beast digestibility of nutrients compared with the other dietary treatments.

Table (8): Effects of date residues and acetic acid on digestibility values (DM, CP, EE, CF and NFE) of Japanese Quails during summer season.

\begin{tabular}{|c|c|c|c|c|c|}
\hline Trait & $\mathrm{DM}(\%)$ & $\mathrm{CP}(\%)$ & $\mathrm{EE}(\%)$ & $\mathrm{CF}(\%)$ & NFE $(\%)$ \\
\hline \multicolumn{6}{|l|}{ Date residues (D) effect: } \\
\hline $\mathrm{D}_{0}$ (zero date residues) control & 70.69 & $75.05^{b}$ & 73.72 & 20.95 & 77.05 \\
\hline $\mathrm{D}_{1}(10 \%$ date residues $)$ & 70.29 & $77.14^{\mathrm{a}}$ & 73.49 & 21.10 & 77.25 \\
\hline Pooled SEM & 0.25 & 0.72 & 0.09 & 0.18 & 0.12 \\
\hline \multicolumn{6}{|l|}{ Acetic acid (A) effect: } \\
\hline $\mathrm{A}_{0}$ (zero acetic acid) control & 70.96 & $73.41^{\mathrm{c}}$ & 73.69 & 21.20 & 77.00 \\
\hline $\mathrm{A}_{1}(0.5 \mathrm{ml} /$ liter $)$ acetic acid & 70.16 & $76.73^{b}$ & 73.55 & 20.87 & 77.19 \\
\hline $\mathrm{A}_{2}(1 \mathrm{ml} /$ liter $)$ acetic acid & 70.40 & $78.15^{\mathrm{a}}$ & 73.58 & 21.01 & 77.26 \\
\hline Pooled SEM & 0.29 & 0.50 & 0.11 & 0.23 & 0.15 \\
\hline \multicolumn{6}{|c|}{ Interactions between date residues (D) and acetic acid (A): } \\
\hline $\mathrm{D}_{0} \mathrm{X} \mathrm{A}_{0}$ & 71.10 & $72.99^{\mathrm{e}}$ & 73.95 & 21.27 & 76.92 \\
\hline $\mathrm{D}_{0} \mathrm{X} \mathrm{A}_{1}$ & 70.27 & $75.20^{\mathrm{d}}$ & 73.63 & 20.65 & 76.97 \\
\hline $\mathrm{D}_{0} \mathrm{X} \mathrm{A}_{2}$ & 70.84 & $76.95^{c}$ & 73.59 & 20.94 & 77.27 \\
\hline $\mathrm{D}_{1} \mathrm{X} \mathrm{A_{0 }}$ & 70.87 & $73.82^{\mathrm{e}}$ & 73.43 & 21.14 & 77.08 \\
\hline $\mathrm{D}_{1} \mathrm{X} \mathrm{A_{1 }}$ & 70.04 & $78.26^{\mathrm{b}}$ & 73.47 & 21.09 & 77.42 \\
\hline $\mathrm{D}_{1} \mathrm{X} \mathrm{A}_{2}$ & 69.96 & $79.35^{\mathrm{a}}$ & 73.59 & 21.07 & 77.26 \\
\hline Pooled SEM & 0.37 & 0.26 & 0.14 & 0.33 & 0.21 \\
\hline
\end{tabular}

Nutrient digestibility improved by adding laying hens quail diets with date residues or/and acetic acid in water could be due to various catalysts such as limiting E.coli population and change in the enteric flora ,lowering gastric $\mathrm{pH}$, synthesizing catabolic enzymes of favorable microorganisms that help in releasing sugar, cell compounds including amino acids and fatty acids in the intestinal environment and the involvement of active bacteria with digestion and absorption of nutrients in the digestive system (Wenk, 2000). In this regard, Fouad and Saleh (2017) reported improved nutrients digestibility by supplementing the quail diet with date waste. 


\section{Bacteriological count :}

The intestinal microbial counts of laying Japanese quails are presented in (Table 9) shows that date residues irrespective of acetic acid and acetic acid irrespective date residues (date's by-product) of level and interactions had significantly $(\mathrm{P}<0.05)$ decreased the intestinal microbial counts, total aerobic and total coliform counts (in compared with the control (zero date residues or acetic acid ). Result showed that bird treated by $1 \mathrm{ml} / 1$ acetic acid in water and date residues $(10 \%)$ into diets had the beast effective against many species of bacteria compared with the other dietary treatments. Organic acids have an antimicrobial effect because they spread through the bacterial cell membrane, and then separate into anions and protons, eventually inhibiting the balance of electrons within cells or actions by suppressing cellular enzymes and transport systems (Luckstadt, 2007; Ricke, 2003 and Strauss and Hayler, 2001). There are many researches refers to the fruitful use of organic acids as an alternative to antibiotics in poultry. For example Alzawqari et al. (2013) reported that the addition of acetic or citric acids to drinking water resulted in a significant decrease in clostridium and coliform in gizzard, cecal and fecal contents of birds with acidified water before slaughter compared with the control and feed withdrawal treatments. Also, Philipsen (2006) revealed the addition of organic acid to drinking water helps reduce the level of pathogens in the water and regulate the small intestine microflora

Table (9): Effects of date residues and acetic acid on count of aerobic, anaerobic and total coliform bacteria in intestine of Japanese quail during summer season.

\begin{tabular}{|c|c|c|c|}
\hline Trait & $\begin{array}{l}\text { Aerobic plate } \\
\text { count } \times 10^{3}\end{array}$ & $\begin{array}{l}\text { Total anaerobic } \\
\text { count } \times 10^{2}\end{array}$ & tal coliform Count $\times 10^{3}$ \\
\hline \multicolumn{4}{|c|}{ Date residues (D) effect : } \\
\hline $\mathrm{D}_{0}$ (zero date residues) control & $8.00^{\mathrm{a}}$ & $0.64^{\mathrm{a}}$ & $24.66^{\mathrm{a}}$ \\
\hline $\mathrm{D}_{1}(10 \%$ date residues $)$ & $3.88^{\mathrm{b}}$ & $0.47^{\mathrm{b}}$ & $10.89^{b}$ \\
\hline Pooled SEM & 0.78 & 0.06 & 2.14 \\
\hline \multicolumn{4}{|c|}{ Acetic acid (A) effect : } \\
\hline $\mathrm{A}_{0}$ (zero acetic acid) control & $8.83^{\mathrm{a}}$ & $0.76 \mathrm{a}$ & $26.00^{\mathrm{a}}$ \\
\hline $\mathrm{A}_{1}(0.5 \mathrm{ml} /$ liter $)$ acetic acid & $5.33^{\mathrm{b}}$ & $0.53^{\mathrm{b}}$ & $14.66^{\mathrm{b}}$ \\
\hline $\mathrm{A}_{2}(1 \mathrm{ml} /$ liter $)$ acetic acid & $3.67^{\mathrm{c}}$ & $0.38^{\mathrm{c}}$ & $12.67^{\mathrm{c}}$ \\
\hline Pooled SEM & 0.96 & 0.05 & 3.16 \\
\hline \multicolumn{4}{|c|}{ Interactions between date residues (D) and acetic acid ( A) : } \\
\hline $\mathrm{D}_{0} \times \mathrm{A}_{0}$ & $9.33^{\mathrm{a}}$ & $0.80^{\mathrm{a}}$ & $26.66^{\mathrm{a}}$ \\
\hline $\mathrm{D}_{0} \mathrm{X} \mathrm{A_{1 }}$ & $8.00^{b}$ & $0.63^{\mathrm{bc}}$ & $24.33^{b c}$ \\
\hline $\mathrm{D}_{0} \times \mathrm{A}_{2}$ & $6.66^{c}$ & $0.50^{\mathrm{cd}}$ & $23.00^{c}$ \\
\hline $\mathrm{D}_{1} \mathrm{X} \mathrm{A_{0 }}$ & $8.33^{\mathrm{ab}}$ & $0.73^{\mathrm{ab}}$ & $25.33^{a b}$ \\
\hline $\mathrm{D}_{1} \mathrm{X} \mathrm{A}$ & $2.66^{\mathrm{d}}$ & $0.43^{\mathrm{d}}$ & $5.00^{\mathrm{d}}$ \\
\hline $\mathrm{D}_{1} \mathrm{X} \mathrm{A}$ & $0.67^{\mathrm{e}}$ & $0.27^{\mathrm{e}}$ & $2.33^{\mathrm{e}}$ \\
\hline Pooled SEM & 0.35 & 0.04 & 0.56 \\
\hline
\end{tabular}

Means with the same letters are not significantly differed at $(P<0.05)$ according to Duncan's multiple range test.

\section{CONCLUSION}

It may be the application of date residues $10 \%$ (in feed) with ( $1 \mathrm{ml} /$ leter) vinegar (acetic acid) in drinking water improved the productive performance such as egg production, fertility, hatchability percentages, some physiological parameters, blood constituents, hormones and immunity, nutrient digestibilities and lowering the intestinal microbial counts of laying Japanese quail during summer season. 


\section{Fouad et al.}

\section{REFERENCES}

A. P. H. A. American Public Health Association (1985). Standard Methods for the Examination of Water and Wastewater, 16th Ed. APHA, Washington, D.C.

A.O.A.C. (1984): Official Methods of Analysis of the Association of Official Analytical Chemists. 14 th ed., Inc., Arlington, Virginia.

A.O.A.C. (1990). Official Methods of Analysis.15thedn,Arlin gton, Virginia,USA.

Abdel-Fattah, S.A., M.H. El-Sanhoury, N.M. El-Mednay and F. Abdel-Azeem (2008). Thyroid activity, some blood constituents, organs morphology and performance of broiler chicks fed supplemental organic acids. Int. J. Poult. Sci., 7: 215-222.

Abdelghani, B. B., Hocine, B. M. and Jamal, M. (2004) Solar drying kinetics temperature change, Labratories des energies nouvelles et renouvelables en zones arides, Ouaragla, Alegeria.

Abramyan, E. and A. Kostanyan (1990). Vitamin C, an antistressor, source (Bibli Ographic Citation): Ptitsevodstovo, 4: 27-28.

Adams, C. (1999). Poultry and dietary acids. Feed Int., 20: 1370-1372.

Adil, S., T. Banday, G.A. Bhat, M.S. Mir and M.Rehman (2010). Effect of Dietary Supplementation of Organic Acids on Performance, Intestinal Histomorphology, and Serum Biochemistry of Broiler Chicken. Vet. Med. Int., vol. Article ID 479485, 7 pages, doi:10.4061/2010/479485.

Al-Harthi, M.A. (2006). The influence of date waste meal supplemented with either enzymes, probiotics or their combination on broiler performance. Egypt. Poult. Sci., 26: 1031-1055.

Alzawqari, M.H., H. Kermanshahi, H.Nassiri Moghaddam, M.H. Tawassoli and A. Gilani (2013). Alteration of gut microflora through citric acid treated drinking water in pre slaughter male broilers. Afr. J. Microb. Res., 7: 564-567.

Anderson, R.A. (1987). Chromium. Trace Elements in Human and Animal Nutrition. Academic Press New York, pp: 225-244.

Ayo, J. O., J. A. Obidi and P. I. Rekwot (2010). Seasonal variations in feed consumption, hen-day, mortality and culls of Bovans Black chickens. in Proceedings of the 35th Annual Conference of the Nigerian Society for Animal Production, pp. 415-418,

Caja, G., D. Garin and J. Mesia (2000). Organic acid slats as growth promoters. Feed International, August, 23-25.

Carpenter, K.J. and K.M. Clegg 1956.The metabolizable energy of poultry feeding stuffs in relation to their chemical composition. J. Sci. Food Agric., 7: 45-51.

Combs, G.F. and G.M. Pesti (1976). Influence of ascorbic acid on selenium nutrition in the chick. J. Nutr., 106: 958-966.

Deeming, D. C. and M. W. J. Ferguson (1991). Physiological effects of incubation temperature on embryonic development in reptiles and birds," in Egg Incubation, Eds., pp. 147-172, Cambridge University Press, Cambridge, UK,

Dibner, J.J. and P. Buttin (2002). Use of organic acids as a model to study the impact of gut microflora on nutrition and metabolism. J. Applied Poult. Res., 11: 453-463.

Donkoh, A. (1989). Ambient temperature: A factor affecting performance and physiological responses of broiler chickens. Int. J. Biometeorol., 33: 259-265.

Duncan, D. B. (1955). Multiple range and multiple F test. Biometrics. 11: 1-42.

FAO. (2007). Food and Agriculture organization of the United Nations. Statistical data bases. Production yearbook. Top Ten dates producers.

Fouad W. and A. A. Saleh (2017). Efficacy of yeast and date's by-product (HAFSH) levels on productive and physiological performance of laying Japanese Quail under high environmental temperature. Egypt. 
Poult. Sci. Vol. (37)(IV): 969-986.

Gama, N.M.S.Q., M.B.C. Olivera, E. Santin and J. Berchieri (2000). Supplementation with organic acids in diets of laying hens. Ciencia Rur. Santa Maria, 30: 4999-4502.

Ghasemi, R., M. Torki, H.A. Ghasemi and M. Zarei (2014). Single or combined effects of date pits and olive on productive traits, egg quality, serum lipids and leucocytes profiles of laying hens. J. Appl. Anim. Res., 42: 103-109.

Gomez, K.A. and A.A. Gomez (1983). Statistical procedures for Agriculture research.A Wiley-Inter Science Publication, John Wiley and sons, Inc. New York, USA.

Guo, Yuming, Caini, Liu, Yuping, Zhou, Y.M. Guo, C.N. Liu and Y.P. Zhou (1998). Impact of heat stress on broilers and the effects of supplemental yeast chromium. Acta. Vetrinaria. et-Zootechnica Sinica., 29: 339-344.

Hamada, J.S., I.B. Hashim and F.A. Sharif (2002). Preliminary analysis and potential uses of date pits in foods. Food Chem., 76: 135-137.

Han, I.K.; H.W. Hochsteler and M.I. Scott (1976). Metabolizable energy value of some poultry feeds determined by various methods and their estimation using metabolizability of dry matter. Poultry Sci. 55: $1335-1342$.

Hermes, I.H. and A.H. Al-Homidan (2004). Effects of using date waste (whole dates and date pits) on performance, egg components and quality characteristics of Baladi Saudi and Leghorn laying hens. Egypt. J. Nutr. Feeds, 7: 223-241.

Hernández, F., V.García, J. Madrid, J. Orengo, P. Catalá and M.D. Megías (2006). Effect of formic acid on performance, digestibility, intestinal histomorphology and plasma metabolite levels of broiler chickens. Br. Poult. Sci., 47: 50-56.

Hussein A.S., G.A. Alhadrami and Y.H. Khalil (1998). The use of dates and date pits in broiler starter and finisher diets. Bioresource Technology, 66: 219-223.

Ishrud, O., M. Zahid, H. Zhou and Y. Pan (2001). A water- soluble galactomannan from the seeds of Phoenix dactylifera L. Carbohydr. Res., 335: 297-301.

Jensen, L.S. and C.H. Chang (1976). Effects of calcium propionate on performance of laying hens. Poult. Sci., 55: 816-817.

Kadim, I.T., B.H.A. Al-Qamshui, O. Mahgoub, W. Al- Marzooqi and E.H. Johnson (2008). Effect of seasonal temperatures and ascorbic acid supplementation on performance of broiler chickens maintained in closed and open-sided houses. Int. J. Poult. Sci., 7: 655-660.

Khan, W.A., Khan-Ahrar, A.D. Anjum and Rehmain-Zia-Ur (2002). Effects of induced heat stress on some biochemical values in broiler chicks. Int. J. Agric. and Biol., 4: 74-75.

Kirunda, D.F., S.E. Scheideler and S.R. McKee (2001). The efficacy of vitamin E (Di-alpha-tocopheryl acetate) supplementation in hen diets to alleviate egg quality deterioration associated with high temperature exposure. Poult. Sci., 80: 1378-1383.

Kutlu, H.R. and J.M. Forbes (1993). Changes in growth and blood parameters in heat stressed chicks in response to dietary ascorbic acid. Livestock Prod. Sci., 72: 335-350.

Lourens, A., H. van den Brand, R. Meijerhof and B. Kemp (2005). Effect of eggshell temperature during incubation on embryo development, hatchability, and post hatch development,". Poult. Sci., 84: 914-920.

Luckstadt, C. (2007). Acidifiers in animal nutrition. Nottingham, UK, Nottingham University Press.

Mahdavi, A.H., H.R. Rahmani and J. Pourreza (2005). Effect of probiotic supplements on egg quality and laying hen's performance. Int. J. Poult. Sci., 4: 488- 492.

Moghaieb R.E.A., A.H.A. Abdel-Hadi and M.R.A. Ahmed (2011). Genetic stability among date palm plantlets regenerated from petiole explants. African J. of Biotechnology, 10: 14311-14318.

Najib, H. and Y.M. Al-Yousef (2012). Effect of enzymatic treatment of Saudi date pits on performance of single comb white leghorn hens and the fatty acid profile of their eggs. Int. J. Poult. Sci., 11: 624-629. 


\section{Fouad et al.}

Novero, R.P., M.M. Beck, E.W. Gleaves, A.L. Johnson and J.A. Deshazer (1991). Plasma progesterone, luteinizing hormone concentrations and granulose cell responsiveness in heat-stressed hens. Poult. Sci., 70: 2335-2339.

Obidi, J. A. , B. I. Onyeanusi, P. I. Rekwot, J. O. Ayo, and T. Dzenda (2008). Seasonal variations in seminal characteristics of Shikabrown breeder cocks. Int. J. of Poult. Sci., 7: 1219-1223.

Owings, W.J., D.L. Reynolds, R.J. Hasiak and P.R. Ferket (1990). Influence of dietary supplementation with Streptococcus faecium M-74 on broiler body weight feed conversion; carcass characteristics and intestinal microbial colonization. Poult. Sci., 69:1257-1264.

Papatsiros, V.G., C. Cristodoulopoulos and L.C. Filippopoulos (2012). The use of organic acids in monogastric animals (swine and rabbits). J. Cell and Anim. Biol., 6: 154-159.

Patten, J.D. and P.W. Waldroup (1998). The use of organic acids in broiler diets. Poult. Sci., 67: 1187- 1182.

Peguri, A. and C. Coon (1991). Effect of temperature and dietary energy on layer performance. Poult. Sci., 70: 126-138.

Philipsen, I.P.L.J. (2006). Acidifying drinking water supports performance. World Poult. Sci., 22, 20-21.

Ricke, S. (2003). Perspectives on the use of organic acids and short chain fatty acids as antimicrobials. Poult. Sci., 82, 632-639.

Sahin N., K. Sahin and O. Kuc“, ,uk (2001). Effects of vitamin E and vitamin A supplementation on performance, thyroid status and serum concentrations of some metabolites and minerals in broilers reared under heat stress $\left(32^{\circ} \mathrm{C}\right)$. Veterinarni Medicina, $46: 286-292$.

Skinner, J.J., A.L. Izat and P.W. Waldroup (1991). Research Note: Dumaric acid enhances performance of broiler chicken. Poult. Sci., 70: 1444- 1447.

Soliman MH. (1996). Use of date stone meal in broiler chicken diets. Egyptian Poult. Sci. J., 16: 187-198.

Soltan, M.A. (2008). Effect of dietary organic acid supplementation on egg production, egg quality and some blood serum parameters in laying hens. Int. J. Poult. Sci., 7: 613-621.

Strauss, G., R. Hayler (2001). Effects of organic acids on microorganisms. Kraftfutter, 4: 147-151.

Sugiharto, S. (2014). Role of nutraceuticals in gut health and growth performance of poultry J. Saudi Society of Agr. Sci., http://dx.doi.org/10.1016/j.jssas.2014.06.001.

Torki M. , H. Zangiabadi and H.A. Ghasemi (2014). Effects of enzyme supplementation on productive performance and egg quality of laying hens fed diets containing graded levels of whole date waste. Poult. Sci., J., 2 (2): 139-151.

Wenk, C.; M. Leonhardt and M. R. L. Scheeder (2000). Monogastric nutrition and potential for improving muscle quality. Pages 199-228 in Antioxidants in Muscle Foods: Nutritional Strategies to Improve Quality. (Ed. E. A. Decker, C. Faustman,and C. J. Lopez-Bote). Wiley Interscience, New York.

Whitehead, C.C., S. Bollengier-Lee, M.A. Mitchell, and P.E.V. Williams (1998). Alleviation of depression in egg production in heat stressed laying hens by vitamin E. Pages 576-578 in Proceeding of $10^{\text {th }}$ European Poultry Conference, Jerusalem, Israel.

Yalcin, S., S. Yalcin, A. Sehu and K. Sarifakiogullari (2000). Yumurta tavugu rasyonlarinda laktik asit kullaniminin bazi yumurta kalite ozelliklerine etkisi. National Animal Nutrition, Congress, Isparta Turkey.

Yesibag, D. and I. Colpan (2006). Effects of organic acid supplemented diets on growth performance, egg production and quality and on serum parameters in laying hens. Revue Med. Vet., 157: 280-284. 
تأثير حامض الخليك ومخلفات التمور على بعض الخصائص الفسيولوجية والانتاجية والتناسليه للسمان خلال فصل

وليد فؤاد احمد طه،، عحمد السيد عيد فراج2 ، بهاء محمد ابو شحيمة22 حسن عبد الكريم حسن عبد الحليم3

اقسم انتاج الدواجن ، كلية الزراعة ، جامعة الوادي الجبلي ، مصر

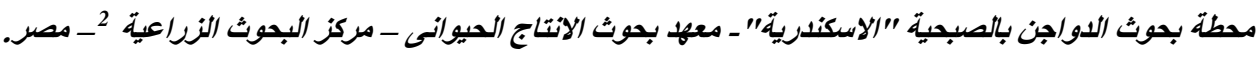

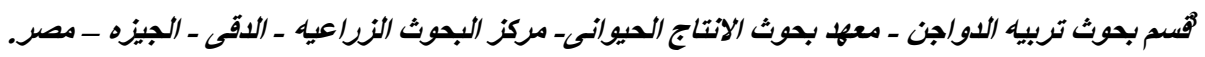





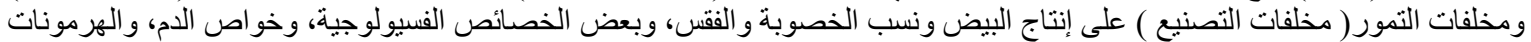

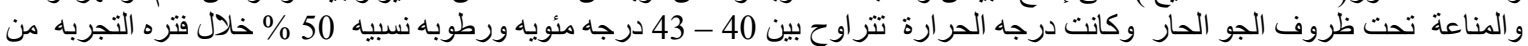
عمر 8 الى 14 أسبوع.

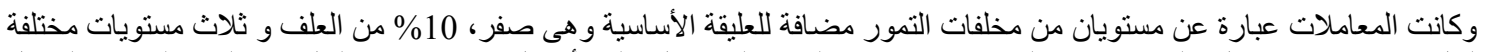



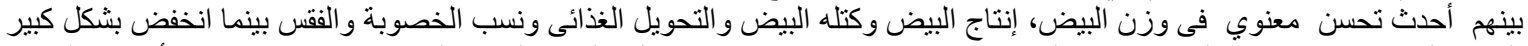

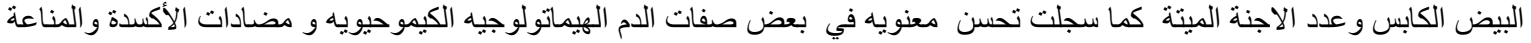

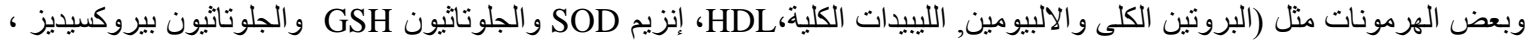

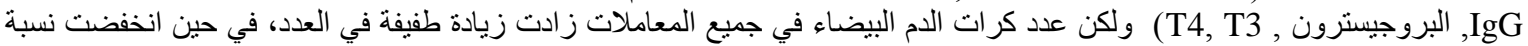

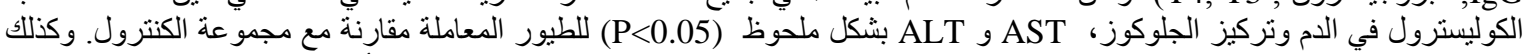

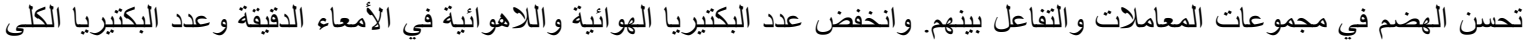
بسبب إضافة المعاملات المختلفة مقارنة مع مجمو عة الكنترول .

مما سبق وجد إن استخدام 10\% مخلفات التمور في العلف مع 1 مل خل / لتر ماء شرب التباء أدى إلى تحسن الأداء الإنتاجي مثل إنتاج

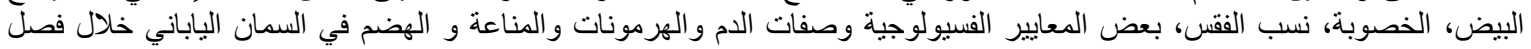
الصيف الحار. 